\title{
Pathogenesis and management of adenoviral keratoconjunctivitis
}

\section{DeGaulle I Chigbu \\ Bisant A Labib}

Pennsylvania College of Optometry, Salus University, Elkins Park, PA, USA

Correspondence: DeGaulle I Chigbu Pennsylvania College of Optometry, Salus University, 8360 Old York Road, Elkins

Park, PA 19027, USA

Tel +l 2I5 99| 4790

Email dchigbu@salus.edu
This article was published in the following Dove Press journal: Infection and Drug Resistance

\begin{abstract}
Human adenovirus (HAdV) is a ubiquitous virus that infects the mucosa of the eye. It is the most common cause of infectious conjunctivitis worldwide, affecting people of all ages and demographics. Pharyngoconjunctival fever outbreak is due to HAdV types 3, 4, and 7, whereas outbreaks of epidemic keratoconjunctivitis are usually caused by HAdV types $8,19,37$, and 54. Primary cellular receptors, such as CAR, CD46, and sialic acid interact with fiber-knob protein to mediate adenoviral attachment to the host cell, whereas adenoviral penton base-integrin interaction mediates internalization of adenovirus. Type 1 immunoresponse to adenoviral ocular infection involves both innate immunity mediated by natural killer cells and type 1 interferon, as well as adaptive immunity mediated mainly by CD8 T cells. The resulting ocular manifestations are widely variable, with pharyngoconjunctival fever being the most common, manifesting clinically with fever, pharyngitis, and follicular conjunctivitis. Epidemic keratoconjunctivitis, however, is the severest form, with additional involvement of the cornea leading to development of subepithelial infiltrates. Because there is currently no US Food and Drug Administration-approved treatment for adenoviral ocular infection, current management is palliative. The presence of sight-threatening complications following ocular adenoviral infection warrants the necessity for developing antiadenoviral therapy with enhanced therapeutic index. Future trends that focus on adenoviral pathogenesis, including adenoviral protein, which utilize host receptors to promote infection, could be potential therapeutic targets, yielding shorter active disease duration and reduced disease burden.
\end{abstract}

Keywords: adenoviral pathogenesis, antiviral therapy, keratoconjunctivitis, tropism

\section{Introduction}

Human adenovirus (HAdV) is a ubiquitous virus that infects various mucoepithelial cells of the body. Primary targets of HAdV infection are eyes, the genitourinary tract, respiratory tract, and gastrointestinal tract. ${ }^{1}$ In fact, HAdV is the most common cause of infectious conjunctivitis and red eye worldwide, accounting for up to $75 \%$ of all conjunctivitis cases and affecting people of all ages and demographics. ${ }^{2}$ Due to its high frequency and many infected patients not seeking medical attention, the incidence is difficult to ascertain. ${ }^{3}$ The majority of adenoviral ocular infections are subclinical, with some being mildly symptomatic and self-limiting. ${ }^{4,5} \mathrm{HAdV}$ infection in immunocompetent individuals is usually subclinical in nature; however, there is likely to be increased ocular morbidity and disease burden in individuals with compromised immune systems. ${ }^{3}$ Morbidity is higher in the pediatric population than the adult population with immunocompromised status. ${ }^{3,6}$ Risk factors for invasive 
and disseminated HAdV include solid-organ or stem-cell transplant and severe immunosuppression. T-cell depletion can result in development of inadequate or lack of cellular immunoresponse to AdV. Depletion of T cells associated with stem-cell transplant, use of long-term immunosuppressants, and absence of $\mathrm{T}$ cells associated with congenital immunodeficiency constitute a significant risk for a persistent and severe course of HAdV infection. ${ }^{6}$

The mode of transmission of AdV-associated ocular infection include direct contact with infected fomites, water, and fecal oral contamination. ${ }^{7}$ It is noteworthy that AdV can survive on a fomite, with the contaminated fomite acting as a medium for transmission. ${ }^{5}$ Pharyngoconjunctival fever (PCF) outbreak is due to HAdV types 3,4 , and $7 .{ }^{8-10}$ Outbreaks of epidemic keratoconjunctivitis (EKC) are usually caused by HAdV types 8, 19, 37, and 54. ${ }^{11-14}$ Periodic outbreaks of AdV ocular infections occur in crowded communities, with children playing a prominent role in maintaining and transmitting the virus to others in their immediate environment. ${ }^{15}$

Its highly contagious nature, long incubation period, and lack of gold standard testing or treatment cause adenoviral conjunctivitis to be a significant global economic burden. ${ }^{16}$ Besides medical costs secondary to nosocomial infections, the failure to diagnose this condition in a timely and accurate fashion leads to an increased number of affected individuals, resulting in excess time away from work and future loss of earning potential due to disability. Misdiagnosis additionally increases health-care spending, due to failure to initiate proper prevention methods, the need for more frequent physician follow-up, and inaccurate prescription of therapeutic agents. ${ }^{16}$ The focus of this review is on the viral pathogenesis of HAdV, clinical ocular manifestations that develop in response to host-defense mechanisms, current laboratory diagnostic methods, and therapeutic approaches to manage these ocular infections.

\section{Adenoviral pathogenesis}

AdV is a lytic, nonenveloped double-stranded DNA virus, with a $36 \mathrm{~kb}$ genome encoding more than 40 structural and nonstructural proteins. ${ }^{17} \mathrm{AdV}$ is $90 \mathrm{~nm}$ in diameter with an icosahedral capsid that contains 240 trimers of hexon protein and 12 pentamers of penton base proteins. Fiber protein protrudes from the penton base and consists of an N-terminal tail in contact with penton base protein and a C-terminal knob domain that serves as a binding site for host cellular receptors. ${ }^{1}$ Classification of AdVs into seven groups $(A-G)$ is on the basis of their hemagglutination properties, tissue tropism, serology, DNA homology, and host-receptor usage. ${ }^{7,18-22}$ The
Human Adenovirus Working Group proposed the characterization and typing of HAdVs on the basis of whole-genome sequence analysis. ${ }^{23}$ To date, there have been 86 types of HAdV reported by this group. ${ }^{24} \mathrm{HAdV}$ belongs to the genus Mastadenovirus and family adenoviridae. ${ }^{18}$

Major structural proteins of AdV include a homopentameric penton base that mediates $\mathrm{AdV}$ internalization into the host, ${ }^{25}$ a homotrimeric fiber protein that plays a role in viral attachment to host cellular receptors, ${ }^{26}$ and hexons that are recognized by neutralizing antibodies. ${ }^{5,7,18}$ Minor capsid proteins include proteins VI, III, VIII, and IX. Core proteins of HAdV include IVa2, V, VII, MU and terminal protein. ${ }^{18,27}$ Primary cellular receptors, such as CAR, ${ }^{28} \mathrm{CD} 46$ (membrane cofactor protein), ${ }^{29}$ sialic acid, ${ }^{30}$ desmoglein $2,{ }^{31}$ heparin sulfate proteoglycans, ${ }^{32} \mathrm{CD} 80, \mathrm{CD} 86,{ }^{33}$ and GD1a, ${ }^{34}$ interact with fiber-knob protein to mediate adenoviral attachment to host cells. ${ }^{1,35}$

The presence of AdV on the ocular surface is associated with activation of ocular surface epithelial cells secreting interleukin 8 (IL8), which binds to its chemokine receptors CXCR1 and CXCR2. The subsequent phosphorylation of downstream molecules culminates in the translocation of CAR and $\alpha_{\mathrm{v}} \beta_{3}$ integrin from the basolateral surface of the polarized epithelial cell to the apical surface to enable interaction of AdV fiber knob with CAR on the apical surface of the epithelial cell. ${ }^{19,35,36}$ Because CD46 is located above the tight junction, it is considered a suitable receptor for mediating adenoviral entry. ${ }^{37}$ It is noteworthy that each of the RGD (arginine-glycine-aspartate) loops on the penton protein serves as a binding site for integrins. ${ }^{37}$ RGD-loop spatial arrangement promotes the signaling process involved in internalization of $\mathrm{AdV}$ into the host cell; however, it does not provide efficient binding site for neutralizing antibodies. ${ }^{18}$ Many epithelial cells express vitronectin-binding integrins $\left(\alpha_{v} \beta_{3}\right.$ and $\left.\alpha_{v} \beta_{5}\right)$ that promote internalization of AdV, depending on the RGD sequence in the penton base protein. ${ }^{25,35,38-40}$ Most HAdVs have the RGD peptide in their penton base, except HAdV-F40, HAdV-F41, and HAdV-D60. ${ }^{4,35}$

Following adenoviral attachment, internalization of $\mathrm{AdV}$ into an endosome is mediated by the interaction of the homopentameric penton base and vitronectin-binding integrin. ${ }^{18,25,37}$ Penton base-integrin interaction activates an intracellular signaling cascade that culminates in the internalization of AdV into clathrin-coated vesicles. ${ }^{18,37,39,41-43}$ Following internalization of the adenoviral nucleocapsid into the endosome, acidification of the endosome is required to initiate several steps involved in the uncoating of $\mathrm{AdV}$. It is of note that the acidic $\mathrm{pH}$ of the endosome triggers the 
AdV-uncoating process and penetration of the endosome. ${ }^{37,44}$ These steps facilitate the release of the viral DNA genome into the nucleus. The first step is vertex dissociation from the adenoviral capsid, a temperature-dependent process that occurs at or near the plasma membrane. Removal of the vertex is followed by further uncoating of the virus in the endosomal pathway, which is linked to endosomal penetration. There is loss of peripentonal hexons, pIIIa, pVIII, and pIX, as well as the release of pVI, a minor capsid protein required for disruption of the endosomal membrane ${ }^{18,37,45-47}$ and facilitation of nuclear importation through movement in a microtubule- and dynein-dependent mechanism and dock at the nuclear pore complex, a proteinaceous channel that mediates movement of the nucleocapsid viral genome into the nucleus, where viral replication takes place. ${ }^{18,37,48,49}$

The replication cycle of AdV consists of an early stage and a late stage. ${ }^{50}$ The early stage of adenoviral replication is characterized by the generation of adenoviral E1A protein (encoded by the $E 1 A$ gene) that transactivates other early genes $E 1 B, E 2, E 3$, and $E 4$, which play important roles in the early stage of the AdV replication cycle. ${ }^{1,50-54}$ Adenoviral DNA replication is dependent on viral DNA polymerase, preterminal protein, and DNA-binding protein. ${ }^{55-58}$ The E2 gene encodes adenoviral DNA polymerase, precursor terminal protein, and DNA-binding protein, which play an important role in viral DNA replication. ${ }^{52,59,60}$ The $E 3$ gene encodes the E3 gp19K protein (E3 Mr 19k glycoprotein), which prevents the display of viral antigen complexed to MHC class 1 molecules on the surface of virally infected cells. ${ }^{61,62}$ The E4 gene encodes E4 proteins, which shut off of host-cell protein synthesis. ${ }^{1,63,64}$ Additionally, this gene is required for the expression of late genes during adenoviral DNA replication. ${ }^{65}$ The late stage of adenoviral replication ensues when late genes encode the adenoviral structural proteins. ${ }^{65-67}$ Adenain (23k cysteine protease), encoded by the $L 3$ gene, promotes maturation and generation of progeny DNA that is packaged in virions. ${ }^{1,37,59}$ Newly generated genome duplexes of $\mathrm{AdV}$ may either enter further replication rounds or undergo processing and encapsidation into virions. ${ }^{59}$

\section{Host response to adenovirus}

The human immune system consists of many levels of defense against invasion by pathogens, including viruses. The epithelium of the ocular surface provides a physical barrier to invasion by viruses and constitutes the first level of defense against pathogens, including AdVs. The chemical barrier, along with the physical barrier, prevents viruses from gaining access to the subepithelial layers of the conjunctiva and cornea. Antimicrobial proteins found in the tear film and expressed by the ocular surface epithelia are innate immune molecules that provide an effective chemical barrier to invading microbes. Defensin is a major antimicrobial protein that possesses antiviral activity. ${ }^{68}$ Nguyen et al ${ }^{69}$ demonstrated that human $\alpha$-defensin blocks the uncoating of AdVs, thereby inhibiting adenoviral infection. In addition to the partial disassembly of the virus, it has been shown that human $\alpha$-defensin inhibits HAdV-mediated endosomalysis. ${ }^{70}$ However, a breach of the physical and chemical barrier results in the initiation of cellular innate immunoresponse and subsequent generation of antiviral immunoresponse. ${ }^{68}$

Innate immunoresponse to adenoviral ocular infection is mediated by natural killer (NK) cells, monocytes, and type 1 interferon (IFN). Adaptive immunity is mediated by IgA, CD8 T cells, and T-helper $1\left(\mathrm{~T}_{\mathrm{H}} 1\right)$ cells. Type 1 IFNs are innate antiviral cytokines, whereas IFN $\gamma$ plays a major role in antiadenoviral adaptive immunoresponse. ${ }^{7,71}$ Additionally, plasmacytoid and conventional dendritic cells participate in immunoresponse to $\mathrm{AdV} .^{38}$ Viral proteins and nucleic acid are virus-associated molecular patterns that bind to patternrecognition receptors on macrophages and dendritic cells, which in turn results in the activation of macrophages to release proinflammatory cytokines, such as IL1 $\beta$, IL6, IL8, IL12, and TNF $\alpha .{ }^{19}$ The activated dendritic cell traffic to regional secondary lymphoid tissue to activate naïve $\mathrm{T}$ cells to generate effector T cells, such as CD8 cytotoxic T cells and $\mathrm{T}_{\mathrm{H}} 1$ cells. $^{71-73}$ Adenoviral infection of plasmacytoid dendritic cells result in adenoviral DNA interacting with TLR9, which results in the production of type 1 IFN. ${ }^{74}$ Additionally, NK cells respond to viral infection by promoting and regulating the adaptive immunoresponse via cross talk with dendritic cells and $\mathrm{T}$ cells, as well as via production of IFN $\gamma$ and TNF $\alpha .{ }^{75}$ It is of note that IFN $\gamma$ secreted by NK cells promotes the upregulation of costimulatory molecules on conventional dendritic cells, priming them for efficient T-cell activation. NK cells are activated by IL12 and type 1 IFN to release IFN $\gamma$, TNF $\alpha$, perforin, and granzyme. ${ }^{75}$

Antibody-mediated response to adenoviral ocular infection is mediated by neutralizing antibodies directed against hexon to prevent hexon-host cell interaction, complementmediated lysis of AdV-infected cells, and antibody-dependent cell-mediated cytotoxicity via NK cells. ${ }^{76}$ Sumida et al ${ }^{77}$ demonstrated that neutralizing antibodies are directed against the hexon protein of AdV. Perforin and granzyme released by cytotoxic T lymphocytes (CTLs) and NK cells are responsible for cell-mediated cytotoxicity of AdV-infected cells, whereas 
IFN $\gamma$ and TNF $\alpha$ released by $T_{H} 1$ cells and CTLs also play a pivotal role in clearance of adenoviral ocular infection. . $2,78,79^{-19}$

Although cell-mediated immunity is necessary for limiting viral growth, $\mathrm{AdV}$ is able to persist in the host via the use of immunoevasive strategies, such as inhibiting antiviral response mediated by IFNs, preventing cytolysis of AdVinfected cells by TNF $\alpha$, promoting intracellular survival by blocking apoptosis of infected cells and evading CTL-mediated cytolysis of infected cells by preventing the display of viral peptide complexed to major histocompatibility complex (MHC) class I molecules on the surface of virally infected cells. ${ }^{80-84}$ Leonard and Sen $^{83}$ demonstrated that adenoviral E1A protein inhibits expression of IFN $\gamma$-inducible genes, which translates to E1A protein-mediated inhibition of IFN $\gamma$ expression. Additionally, EIA protein has an inhibitory effect on IFN $\alpha$, a potent innate antiviral cytokine.$^{83}$ Lesokhin et $\mathrm{a}^{15}$ demonstrated that adenoviral E3 protein can inhibit the ability of TNF $\alpha$ to induce the secretion of chemokines, such as IL8 and MCP1. Adenoviral E3 protein (E3-14.7K) blocks the ability of TNF $\alpha$ to induce the apoptosis of AdV-infected cells. ${ }^{86,87}$ Adenoviral virus-associated-inducible RNA antagonizes the activation of IFN-induced dsRNA-activated protein kinase, a protein that plays an important role in mediating the antiviral action of IFN. ${ }^{88}$

NK cells are one of the first responding lymphocytes of the innate immune system in cases of viral infection of mucosal surfaces, such as the conjunctiva, which are responsible for cytokine production, apoptosis, and engaging the cellmediated immunoresponse. ${ }^{75,89}$ Studies have reported that AdVs retain the ability, through the use of multiple pathways, to inhibit the NK response in the early and acute stages of the conjunctivitis. This is able to occur through the upregulation of inhibitory ligand human leukocyte antigen $\mathrm{E}$, in addition to the downregulation of several ligands that are responsible for the initiation of NK-cell-activating receptors. ${ }^{90}$ Additionally, concomitant downregulation of human leukocyte antigen $\mathrm{A} / \mathrm{B} / \mathrm{C}$ expression is a strategy used by the virus to modulate MHC class I expression in infected conjunctival epithelium. Group D HAdV evades immunomediated cytolysis by downregulating expression of ligands (CD112 and CD155) for activating NK cell receptor DNAM1/CD226, which in turn translates to impairment of NK-cell-mediated immunity against AdV. This allows the virus to remain active on the conjunctival surface and give rise to persistent infection. ${ }^{75}$

\section{Viral and tissue tropism}

Adenoviral tropism is related to affinity of host cellular receptors for fiber knob for viral entry and penton base for viral internalization. ${ }^{5}$ Binding affinity for host cellular receptors plays a role in viral tropism, with broadening of viral tropism linked to degree of binding affinity. ${ }^{35}$ As such, affinity between virus and cellular receptors is likely to be high if few receptor molecules are adequate to produce an infection. If binding sites on cellular receptors are masked or many receptor molecules required to cause infection, such affinity of the interaction between virus and cellular receptor is low. ${ }^{35} \mathrm{HAdVA},-\mathrm{C}$, -D, -E, and -F species use CAR, ${ }^{91}$ whereas HAdVB species use $\mathrm{CD} 46^{92-94}$ or membrane glycoprotein desmoglein $2^{31}$ as cellular receptor for viral attachment. Species HAdVD37 utilizes sialic acid $^{30}$ and GD1 $\mathrm{a}^{34}$ as cellular receptors to infect the eye, whereas species HAdVD8 and -D19 utilize CAR and sialic acid as cellular receptors to cause ocular infection. ${ }^{20,91}$ Tissue tropism of AdV is dependent on the affinity between viral attachment proteins and host cellular receptors, as well as adenoviral grouping. It is of note that HAdVD species have affinity for ocular tissues, and as such they are implicated in adenoviral ocular surface infections. ${ }^{5}$

\section{Clinical manifestations}

Clinical manifestation of adenoviral ocular infection is usually lytic in nature, with persistent infection attributed to latent $\mathrm{AdV}$ infection. ${ }^{5,95}$ Lytic infection occurs upon completion of the viral replicative cycle in permissive cells, with release of up to 1 million progeny viruses per cell, of which up to $5 \%$ of virions are capable of causing infection. ${ }^{5,7}$ Chronic or latent AdV infection is characterized by production of small amounts of virus, which serves as a source for nosocomial spread of AdV in hospitals, chronic-care facilities, and day-care centers. ${ }^{7}$ PCF is caused by HAdV types 1, 2, 3, 4, 5, and 7 and is associated with swimming in insufficiently chlorinated pools and lakes (Table 1). ${ }^{5,76,96} \mathrm{In}$ contrast, EKC is a highly contagious ocular infection caused by AdV types 8, 19, 37, 53 and 54. EKC usually occurs as an outbreak emanating from eye clinics with contaminated instruments and solutions (Table 1). 5,7,97

Table I Overview of ocular involvement and clinical manifestations with specific adenoviral serotypes $2,8-10,12-14,37,41,99,100,106,110$

\begin{tabular}{lll}
\hline Ocular structure & Clinical manifestations & Subtypes involved \\
\hline Adnexa & $\begin{array}{l}\text { Eyelid edema, lacrimal gland } I-5,7,8,19,37, \\
\text { enlargement, nasolacrimal }\end{array} 53,54$ \\
& duct inflammation \\
Conjunctiva & $\begin{array}{l}\text { Follicles, hyperemia, edema, } I-5,7,8,19,37, \\
\text { petechial hemorrhages, } \quad 53,54\end{array}$ \\
& $\begin{array}{l}\text { pseudomembranes } \\
\text { Cornea }\end{array}$ & $\begin{array}{l}\text { Multifocal punctate keratitis, 8, } 19,37,53,54 \\
\text { subepithelial infiltrates }\end{array}$ \\
\hline
\end{tabular}


The ocular manifestations of HAdV infections are widely variable. PCF is the most common presentation, primarily affecting children. ${ }^{98}$ Conjunctival entry of AdV has been investigated using microarray technology, which demonstrated that nuclear localization of the virus occurred about 1.5 hours following infection, inducing early transcription followed by late transcription hours later. ${ }^{80}$ PCF manifests clinically with fever, pharyngitis, rhinitis, follicular conjunctivitis, and regional lymphoid hyperplasia. Replication of AdV in the conjunctiva is associated with follicular hypertrophy, edema, hyperemia, and petechial hemorrhages. ${ }^{5,8,10,99,100}$ Conjunctival hyperemia and edema are attributed to acute inflammation induced by innate immunoresponse to $\mathrm{AdV}$ in the conjunctiva. Proinflammatory cytokines, such as $\mathrm{TNF} \alpha$ released during the innate immunoresponse, induce conjunctival vasodilation and capillary leakage, which results in conjunctival hyperemia and edema, respectively. Petechial hemorrhages are due to AdV-induced vasculitis, which is associated with persistent $\mathrm{AdV}$-induced conjunctival inflammation, in which dilated conjunctival capillaries become compromised and fragile with consequential increased capillary permeability and rupture of conjunctival capillaries (Figure 1). ${ }^{72,101}$ The appearance of follicular response, which appears as avascular, round, or oval clusters of lymphocytes, depends on the patient's immunoresponse to the AdV infection. ${ }^{72}$ Pseudomembranes are likely due to exudation of serum, fibrin, and leukocytes from dilated capillaries in the conjunctiva and follicular reaction in the inflamed palpebral conjunctiva. ${ }^{2,101}$ Pseudomembranes consist of leukocytes, necrotic epithelial tissue, and fibrin on the inflamed surface of the palpebral conjunctiva. Pseudomembranes could potentially form a conjunctival scar and symblepharon if they are not removed. ${ }^{2,102}$ Pseudomembranes are always present in the more symptomatic eye (Figure 2). ${ }^{103}$ PCF is typically self-limiting and will resolve in 2-3 weeks. ${ }^{2}$

EKC is the most severe form of ocular HAdV infection. ${ }^{2,104,105}$ Patients will often report redness, tearing, foreign-body sensation, and photophobia. They may also have flu-like symptoms, such as generalized fever, malaise, and myalgia. ${ }^{3,100}$ Magnetic resonance imaging in EKC reveals that there is even deeper penetration of ocular tissue, with evidence of associated eyelid edema and lacrimal gland enlargement. It is also often accompanied by nasolacrimal duct inflammation, giving rise to excessive symptomatic tearing in these patients. ${ }^{100,106}$ It is noteworthy that AdV infection of the ocular surface primarily affects the conjunctival surface, but in EKC, AdV may also gain entry into the cornea, inducing innate and cell-mediated immunoresponses. ${ }^{75,80}$

The most unique characteristic of this type of conjunctivitis is its ability to gain entry into the cornea, resulting in a

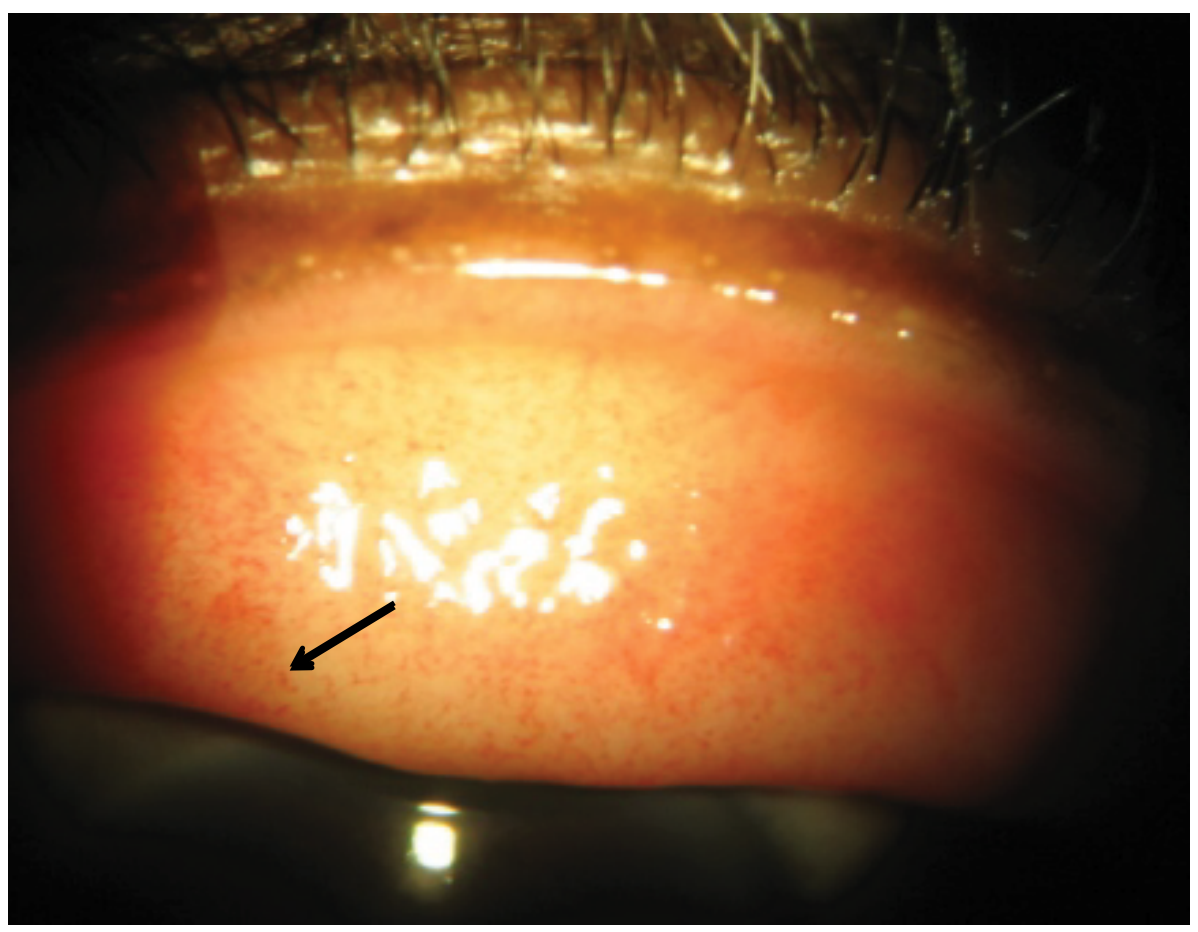

Figure I Slit-lamp photography of superior palpebral conjunctiva with petechial hemorrhages (black arrow) in a patient with adenoviral keratoconjunctivitis. Note: Courtesy of DeGaulle I Chigbu. 


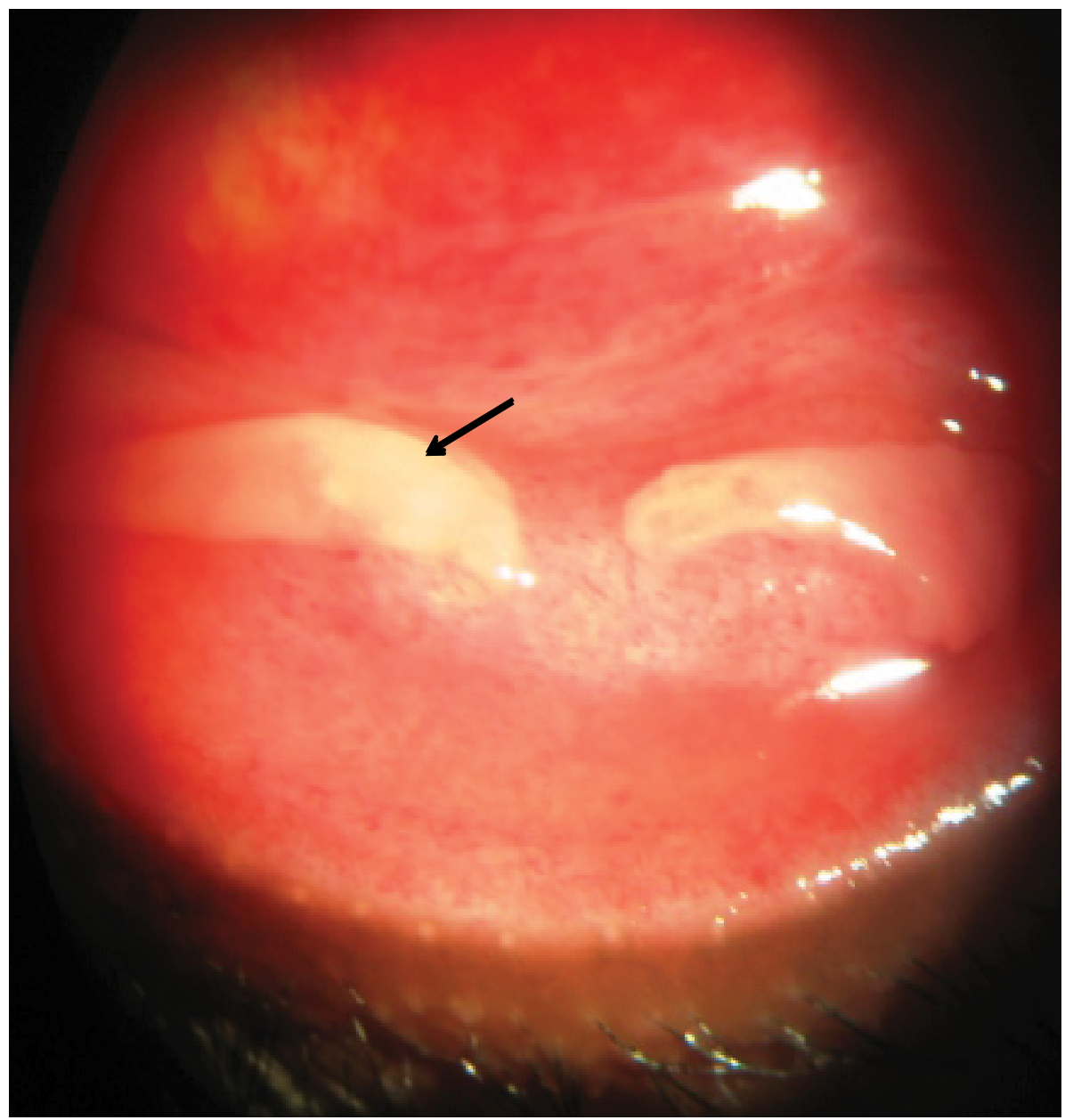

Figure 2 Slit-lamp photography of inferior palpebral conjunctiva with pseudomembrane (black arrow) in a patient with adenoviral keratoconjunctivitis. Note: Courtesy of DeGaulle I Chigbu.

severe inflammatory response that often leads to detrimental visual disturbance. ${ }^{106}$ This inflammatory response is as a result of several factors. It is well documented that the corneal stroma houses a significant number of cells, including fibroblasts, dendritic cells, and macrophages. As such, these cells respond greatly in cases of infection or insult, resulting in the production of chemokines that facilitate leukocytic infiltration. ${ }^{74}$ The entry of AdV into the cornea begins with its entry to the cell membrane following initial infection. Next, cell binding occurs as the virus makes its way to the cytoplasm, yielding intracytoplasmic accumulation and subsequent clinically evident stromal inflammation shortly thereafter. ${ }^{107,108}$ It is of note that the process through which the virus enters the host is clathrin-mediated endocytosis. Caveolae, lipid rafts that allow entry into the plasma membrane, contain the membrane protein caveolin 1, a ubiquitous protein in several cell types, mainly fibroblasts. AdVs use this pathway to gain access into the cornea. ${ }^{41}$

Corneal involvement may begin as early as $2-3$ days following initial clinical presentation. Changes to the corneal tissue that occur following the immunoresponse are seen clinically as keratitis, often associated with adenoviral keratoconjunctivitis. Multifocal punctate keratitis is usually due to replication of the AdV in the corneal epithelium, and this gradually develops into focal areas of epithelial opacities. ${ }^{109}$ Approximately $7-10$ days following the initial clinical manifestation of EKC, multiple, focal subepithelial infiltrates (SEIs) arise in the anterior stroma of the cornea. ${ }^{13}$ Interaction of adenoviral virus-associated molecular patterns with pattern recognition receptors on superficial keratocytes is associated with infection and activation of keratocytes in the anterior corneal stroma, with consequential upregulation of proinflammatory mediators, such as chemokines. IL8 and MCP1 are chemokines released by AdV-infected keratocytes that mediate leukocyte infiltration in AdV-infected corneal stroma. IL8 recruits neutrophils, whereas MCP1 recruits monocytes and T cells. Accumulation of lymphocytes, macrophages/monocytes, and activated fibroblasts in response to AdV-infected corneal keratocytes is a hallmark histopathological feature of subepithelial (stromal) corneal 
infiltrates. ${ }^{110-113}$ These opacities may persist for up to several weeks to years and have the tendency to result in visual decrease, glare, photophobia, and irregular astigmatism. ${ }^{3,110}$ Kaye et $\mathrm{al}^{114}$ used primers for AdV hexon genes to amplify extracted adenoviral DNA from ocular samples of patients who had a history of AdV. These researchers were able to demonstrate the presence of amplifiable adenoviral DNA in ocular samples, such as tears, indicating that the presence of adenoviral DNA was associated with chronic papillary conjunctivitis. As such, chronic or recurrent papillary conjunctivitis in patients with previous AdV-related keratoconjunctivitis is associated with the persistence of adenoviral DNA in the tear film and conjunctiva. ${ }^{114}$

\section{Laboratory diagnostic methods}

The diagnosis of ocular HAdV infection is mainly based on clinical examination. However, some laboratory tests are available to aid in the confirmation of the diagnosis. The first method of identification is the isolation of the virus in cell cultures, using HEK cell cultures, or through the use of complement fixation test. ${ }^{115,116}$ In HEK cell cultures, samples are obtained from the conjunctiva of affected patients and inoculated into HEK cells to analyze structural changes to host cells from viral invasion. Complement fixation test methods involve blood samples tested for the detection of antibodies related to AdV infection. Side-by-side comparison of these two methods indicates superior sensitivity with HEK cell culture testing. ${ }^{115}$ The limitation is the timing of laboratory testing, in that it takes $\sim 1-2$ weeks for results to be made available. ${ }^{116}$

Polymerase chain reaction assays offer a timely and more sensitive approach to laboratory diagnosis of HAdV when compared with cell cultures. This method utilizes the extraction of conjunctival samples with polymerase chain reaction amplification and full characterization with gel electrophoresis to identify the presence of HAdV. The drawback of this procedure, however, is that is not usually able to be performed on-site and transport of cell samples are necessary. ${ }^{2,22}$

Most recently, the US Food and Drug Administration (FDA) approved rapid antigen-detecting kits that can be used chairside as a point-of-care test to diagnose adenoviral conjunctivitis. ${ }^{117}$ The Rapid Pathogen Screening AdenoDetector utilizes lateral flow immunochromatography, which identifies the hexon protein portion of HAdV to diagnose quickly and accurately the presence of $\mathrm{AdV}$ on the ocular surface. ${ }^{18,119}$ The procedure for this test involves collecting a tear sample from multiple areas of a patient's conjunctiva during his or her active disease. The sample is then placed in a buffer solution, where it sits for 10 minutes, finally indicating a positive test denoted by one blue control line and one red test line or a negative test denoted by only the blue control line. ${ }^{120}$ It is able to detect 53 types of HAdV with an $88 \%$ sensitivity and $91 \%$ specificity. ${ }^{2,118}$

\section{Clinical management}

Clinical management of ocular AdV infections is targeted to provide relief of symptoms, as well as shorten the duration of infection. Although adenoviral conjunctivitis is a self-limiting condition typically lasting 2-3 weeks, treatment options have been investigated to alleviate symptoms or shorten time of infection. Patients with adenoviral ocular infection are highly contagious for the first 2 weeks after onset of symptoms. Because $\mathrm{AdV}$ is an nonenveloped virus, it can survive on inanimate objects for several weeks after contamination. ${ }^{121,122}$ Outbreaks of adenoviral ocular infection have been linked to transmission of $\mathrm{AdV}$ from contaminated ophthalmic equipment, environmental surfaces, multipurpose eyedrops, and contaminated hands of health-care workers. ${ }^{121}$ As such, it is important to institute appropriate levels of infectious disease control measures to reduce the ability of contaminated instruments in the eye clinic to serve as a source of transmitting the viral infection to other patients. ${ }^{121,122}$ Infection control measures include reeducating health-care workers on the importance of personal hygiene via handwashing before and after patient contact, high-level disinfection of shared or reusable equipment that come into contact with patient eyes or bodily fluids being immersed in 3\% hydrogen peroxide for a minimum of 10 minutes, designating an examination room for triaging patients with suspected adenoviral ocular infections, and use of disposable tonometer tips and singledose eyedrops in the eye clinic (Figure 3). ${ }^{121,123}$ Surfaces within the examination room should be cleaned and disinfected as a means of reducing transmission of HAdV to other patients. ${ }^{124}$ Tonometry and other procedures requiring contact with ocular surfaces should be postponed. Patients should be instructed to reduce transmission risk via avoidance of eye touching and sharing such items as towels and pillowcases. ${ }^{125}$ Patients should also be advised to stay isolated during the infective phase, as well as thoroughly educated on the normal course of the disease to prevent the need for frequent office follow-ups. ${ }^{123}$

There is currently no FDA-approved treatment for ocular HAdV. However, antiviral drugs, such as ganciclovir and cidofovir, have demonstrated promise in the treatment of various HAdV types with in vitro studies. ${ }^{53}$ Cidofovir is a nucleoside analog that was developed to fight against DNA 

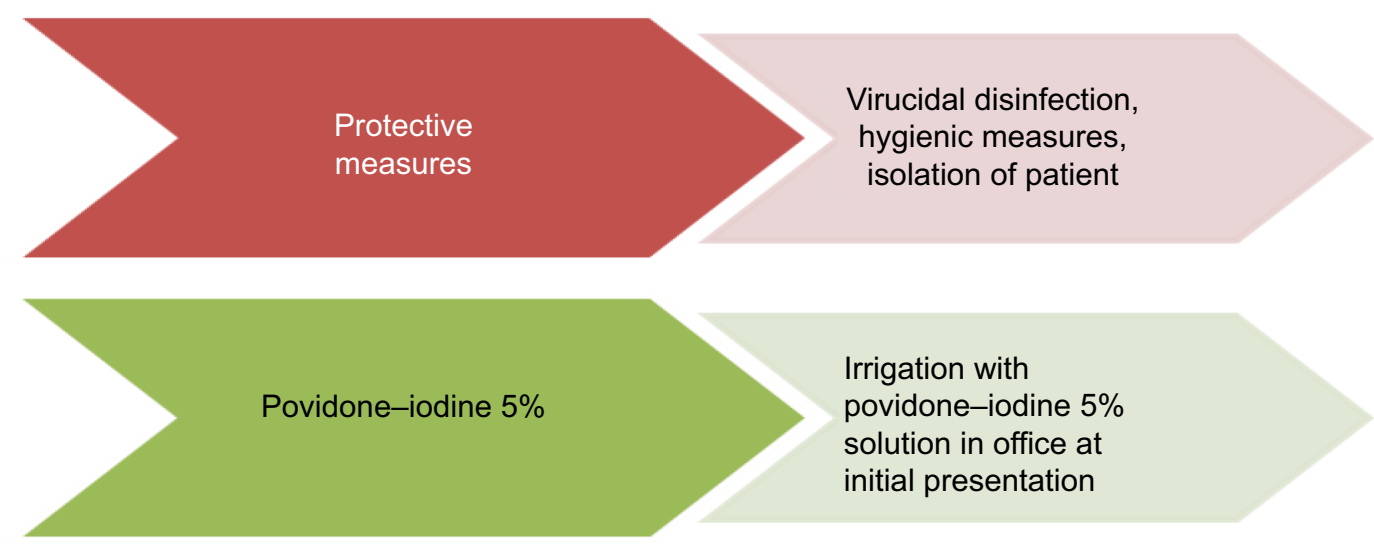

Irrigation with

povidone-iodine $5 \%$

solution in office at

initial presentation

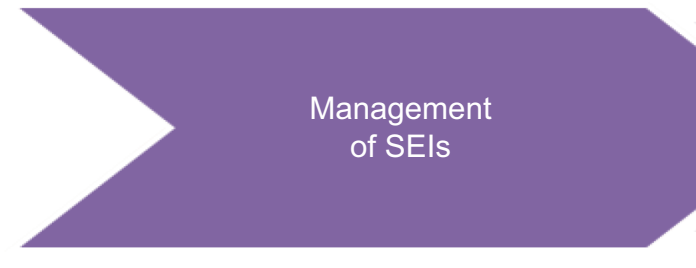

Figure 3 Flowchart highlighting management efforts for EKC patients. 2,121-123,127,|141,143 Abbreviations: EKC, epidemic keratoconjunctivitis; SEls, subepithelial infiltrates.

viruses, as it directly passes the cell membrane and targets the DNA polymerase of the virus to halt replication. ${ }^{26}$ Topical application to the ocular surface reduces time and exposure of viral shedding. The utilization of cidofovir for the treatment of HAdV is controversial, as studies have not exhibited a statistically significant improvement in the amelioration of symptoms or course of the disease., ${ }^{2,53}$ It has also been demonstrated to cause substantial ocular toxicity, even at low doses, making it of little clinical value. ${ }^{127,128}$

Ganciclovir is also a synthetic nucleoside analog inhibiting DNA polymerase and effective against several DNA viruses, most notably the herpes family. ${ }^{53,129}$ The marginal efficacy of ganciclovir in treating adenoviral keratoconjunctivitis could be attributed to the lack of viral thymidine kinase in $\mathrm{AdV}^{6,129,130}$ It has been suggested that valganciclovir, a prodrug of ganciclovir, inhibits DNA replication of AdV via blockade of adenoviral DNA polymerase and induction of intracellular modification of purine-pyrimidine nucleotide balance. ${ }^{131,132}$ In an in vitro-based study, Huang et al demonstrated the dose-dependent antiadenoviral effect of ganciclovir on HAdV3, $-4,-8,-19$, and -37 species associated with ocular adenoviral keratoconjunctivitis. They suggested that commercially available ganciclovir ophthalmic gel $0.15 \%$ may be therapeutically beneficial. ${ }^{129} \mathrm{~A}$ small-scale study has indicated the potential of ganciclovir in the inhibition of the formation of SEIs; however, larger scale data are lacking. ${ }^{119,133}$

Topical immunoglobulin (Ig) also has exhibited antiviral activity, specifically with HAdV, in both in vitro and in vivo studies by successfully neutralizing the virus on the ocular surface. Ig shows promise in that it can act in the early phases of infection, aiding in viral clearance for earlier resolution of clinical symptoms and prophylaxis against future infection, as it is known also to demonstrate broad-spectrum antimicrobial characteristics. Though studies have displayed success with Ig as a potential treatment for EKC and AdV-related conjunctivitis, the availability of it from serum donors as a topical solution is questionable, due to issues with product consistency. ${ }^{134}$ Also, despite success with animal in vivo studies, human data are lacking. ${ }^{2}$

Because the course of HAdV infection in immunocompromised patients is usually severe and persistent, antiadenoviral chemotherapy and cellular immunotherapy would be therapeutically beneficial. Antiviral chemotherapy have shown promise in treating immunocompromised individuals with adenoviral infection. Cidofovir and ganciclovir have been used as antiviral pharmacotherapy in immunocompromised individuals with adenoviral infection. Brincidofovir is a lipid conjugate of cidofovir with reduced propensity to cause nephrotoxicity usually associated with cidofovir. It is more orally bioavailable than cidofovir. Brincidofovir has demonstrated significant antiadenoviral activity. ${ }^{6,135}$ Grimley et al ${ }^{136}$ demonstrated the antiadenoviral activity of brincidofovir in immunocompromised pediatric and adult patients. Toth et a ${ }^{137}$ demonstrated the antiadenoviral efficacy of combination therapy of brincidofovir and valganciclovir, which translated to reduced dose and duration of therapy. This could be a very 
beneficial therapeutic strategy for immunocompromised patients. Adoptive transfer of HAdV-specific T cells is a beneficial cellular immunotherapeutic strategy for treating adenoviral infections in immunocompromised individuals, such as recipients of hematopoietic stem cell transplants. ${ }^{6}, 138$ The adoptive transfer of HAdV-specific T cells boosts antiadenoviral cellular immunity. Zandvliet et a $\mathrm{a}^{139}$ demonstrated that HAdV hexon-specific T cell-adoptive immunotherapy resulted in the generation of $\mathrm{CD} 8^{+}$and $\mathrm{CD} 4^{+} \mathrm{T}$-cell immunoresponse that cleared adenoviral infection in immunocompromised patients. The use of adoptive HAdV-specific T-cell transfer is an effective immunotherapeutic protocol and is an alternative to the use of antiviral chemotherapy to treat adenoviral infection in immunocompromised individuals. ${ }^{140}$

Povidone-iodine, an antiseptic often used for sterilization prior to general and ocular surgery, has broad-spectrum antimicrobial properties to inhibit various bacteria, viruses, fungi, and other organisms. ${ }^{127}$ As such, its potential use in the treatment of HAdV has been and is currently still under investigation. Povidone-iodine 5\% solution alone is often used in clinical practice as in-office irrigation to decrease viral spread. Potential efficacy with povidone-iodine in conjunction with a topical corticosteroid is also favorable, in that the steroidal component provides symptomatic relief while the povidoneiodine destroys the virus. ${ }^{2,127,141}$ Phase II clinical trials are under way for a combination povidone-iodine $0.4 \%$-dexamethasone $0.1 \%$ ophthalmic suspension, showing promise as a future treatment approach to ocular AdV ${ }^{141}$ Most recently, a controlled randomized study utilizing povidone-iodine $1.0 \%$ and dexamethasone $0.1 \%$ eyedrops concluded that patients placed on this regimen had nearly complete recovery of signs and symptoms of adenoviral infection in as little as 5 days. ${ }^{122}$ Using this combination four times per day was superior to patients using artificial tears only or those using dexamethasone $0.1 \%$ only. This was likely due to the fact that the povidone-iodine inhibited viral replication, exhibiting antiviral effects, while the dexamethasone component served as an anti-inflammatory component and alleviated patient symptoms. It was also highlighted that patients treated too early with a corticosteroid alone, such as the dexamethasone-only control group, may actually show in increased viral replication and prolonged viral shedding, a mechanism that is counteracted with the adjunct use of povidone-iodine (Figure 3). ${ }^{142}$

Despite the self-limiting nature of ocular AdV, SEIs may remain well after the infection subsides. Topical corticosteroids alone are implicated in their treatment in the capacity that they may aid in clearance of these often visually significant opacities. The drawbacks of corticosteroid use in these cases are many, in that the SEIs often return following discontinuation. ${ }^{2}$ Treating with corticosteroids in the active phase of the infection may also be detrimental in that it has been shown actually to prolong viral shedding and inhibit immunoclearance. ${ }^{119,127}$ This is apart from the other known negative side effects of prolonged corticosteroid use: glaucoma and cataract formation. Due to the negative effects of corticosteroids, $0.05 \%$ and $2 \%$ cyclosporine, as well as tacrolimus $0.03 \%$ agents, may instead be beneficial in clearance of SEIs without the damaging potential outcomes (Figure 3). ${ }^{127,143}$

\section{Conclusion}

The presence of sight-threatening complications postocular adenoviral disease warrants the necessity of developing antiadenoviral therapy with enhanced therapeutic index and safety profile. ${ }^{21}$ As such, adenoviral genes and proteins involved in the process of adenoviral pathogenesis could serve as potential therapeutic targets for developing antiviral therapy. Currently, investigations are under way targeting genes that are important in initiating adenoviral replication. Furthermore, caveolin is a known important mediator for adenoviral infection of corneal cells. It has been reported that HAdVD37 can enter corneal fibroblasts via the caveolin 1-associated lipid-raft-specific pathway, in which, there is triggering of caveosomal signaling and expression of proinflammatory mediators, and it is possible that lipid-raftmediated endocytosis could be a target for antiviral therapy in adenoviral corneal infection. ${ }^{41}$ There is also ongoing research on the use of RNA interference to mediate the silencing of viral genes required for viral replication via siRNA, short-hairpin RNA, or artificial miRNA. ${ }^{144}$ RNAi-mediated silencing of early and late genes of AdVs, specifically or particularly DNA polymerase and preterminal proteins, can inhibit viral replication. ${ }^{51}$ Using primary human limbic cells, Nikitenko et al ${ }^{145}$ demonstrated the ability of siRNA to downregulate replication of viral DNA in HAdVD species (D8 and D37) via silencing of $E 1 A$ and $E 2 B$ mRNA. They demonstrated that downregulation of $E 1 A$ gene expression in HAdV species D8, D19, and D37 using siRNA inhibited AdV DNA replication with consequential blockade of AdV multiplication. ${ }^{145}$ Therefore, it is imperative to develop antiviral therapy that targets specific proteins required for HAdV survival, with the intent of reducing AdV-associated ocular complications and disease burden.

\section{Disclosure}

The authors report no conflicts of interest in this work. 


\section{References}

1. Gonçalves MA, de Vries AA. Adenovirus: from foe to friend. Rev Med Virol. 2006;16(3):167-186.

2. Jhanji V, Chan TC, Li EY, Agarwal K, Vajpayee RB. Adenoviral keratoconjunctivitis. Surv Ophthalmol. 2015;60(5):435-443.

3. Ghebremedhin B. Human adenovirus: viral pathogen with increasing importance. Eur J Microbiol Immunol (Bp). 2014;4(1):26-33.

4. Robinson CM, Zhou X, Rajaiya J, et al. Predicting the next eye pathogen: analysis of a novel adenovirus. mBio. 2013;4(2):e00595-e00512.

5. Rhee E, Barouch D. Adenoviruses. In: Bennett J, Dolin R, Blaser M, editors. Mandell, Douglas, and Bennett's Principles and Practice of Infectious Diseases. 8th ed. Philadelphia: Saunders; 2015:1787-1793.

6. Lion T. Adenovirus infections in immunocompetent and immunocompromised patients. Clin Microbiol Rev. 2014;27(3):441-462.

7. Gray G. Adenovirus vaccines. In: Plotkin SA, Orenstein WA, Offit PA, editors. Vaccines. 6th ed. Philadelphia: Saunders; 2013:113-126.

8. Artieda J, Pineiro L, Gonzalez M, et al. A swimming pool-related outbreak of pharyngoconjunctival fever in children due to adenovirus type 4, Gipuzkoa, Spain, 2008. Euro Surveill. 2009;14(8):19125.

9. Xie L, Yu XF, Sun Z, et al. Two adenovirus serotype 3 outbreaks associated with febrile respiratory disease and pharyngoconjunctival fever in children under 15 years of age in Hangzhou, China, during 2011. J Clin Microbiol. 2012;50(6):1879-1888.

10. Harley D, Harrower B, Lyon M, Dick A. A primary school outbreak of pharyngoconjunctival fever caused by adenovirus type 3. Commun Dis Intell. 2001;25(1):9-12.

11. Zhang L, Zhao N, Sha J, et al. Virology and epidemiology analyses of global adenovirus-associated conjunctivitis outbreaks, 1953-2013. Epidemiol Infect. 2016;144(8):1661-1672.

12. d'Angelo LJ, Hierholzer JC, Holman RC, Smith JD. Epidemic keratoconjunctivitis caused by adenovirus type 8: epidemiologic and laboratory aspects of a large outbreak. Am J Epidemiol. 1981;113(1):44-49.

13. Richmond S, Burman R, Crosdale E, et al. A large outbreak of keratoconjunctivitis due to adenovirus type 8. J Hyg (Lond). 1984;93(2):285-291.

14. Lee YC, Chen N, Huang IT, et al. Human adenovirus type 8 epidemic keratoconjunctivitis with large corneal epithelial full-layer detachment: an endemic outbreak with uncommon manifestations. Clin Ophthalmol. 2015;9:953-957.

15. Ford E, Nelson KE, Warren D. Epidemiology of epidemic keratoconjunctivitis. Epidemiol Rev. 1987;9:244-261.

16. Stenson S, Newman R, Fedukowicz H. Laboratory studies in acute conjunctivitis. Arch Ophthalmol. 1982;100(8):1275-1277.

17. Schaar K, Röger C, Pozzuto T, Kurreck J, Pinkert S, Fechner H. Biological antivirals for treatment of adenovirus infections. Antivir Ther. 2016;21(7):559-566.

18. Nemerow GR, Pache L, Reddy V, Stewart PL. Insights into adenovirus host cell interactions from structural studies. Virology. 2009;384(2): 380-388.

19. Lütschg V, Boucke K, Hemmi S, Greber UF. Chemotactic antiviral cytokines promote infectious apical entry of human adenovirus into polarized epithelial cells. Nat Commun. 2011;2:391.

20. Cupelli K, Stehle T. Viral attachment strategies: the many faces of adenoviruses. Curr Opin Virol. 2011;1(2):84-91.

21. Lenaerts L, Naesens L. Antiviral therapy for adenovirus infections. Antiviral Res. 2006;71(2-3):172-180.

22. Gainotti R, Ricarte C, Ebekian B, et al. Real time PCR for rapid determination of susceptibility of adenovirus to antiviral drugs. JVirol Methods. 2010;164(1-2):30-34.

23. Seto D, Chodosh J, Brister JR, Jones MS. Using the whole-genome sequence to characterize and name human adenoviruses. $J$ Virol. 2011;85(11):5701-5702

24. Human Adenovirus Working Group [homepage]. Available from: http:// hadvwg.gmu.edu. Accessed April 29, 2018.

25. Wickham TJ, Mathias P, Cheresh DA, Nemerow GR. Integrins $\alpha_{\mathrm{v}} \beta_{3}$ and $\alpha_{\mathrm{v}} \beta_{5}$ promote adenovirus internalization but not virus attachment. Cell. 1993;73(2):309-319.
26. Walters RW, Freimuth P, Moninger TO, Ganske I, Zabner J, Welsh MJ. Adenovirus fiber disrupts CAR-mediated intercellular adhesion allowing virus escape. Cell. 2002;110(6):789-799.

27. Saban SD, Silvestry M, Nemerow GR, Stewart PL. Visualization of $\alpha$-helices in a 6-angstrom resolution cryoelectron microscopy structure of adenovirus allows refinement of capsid protein assignments. JVirol. 2006;80(24):12049-12059.

28. Bergelson JM, Cunningham JA, Droguett G, et al. Isolation of a common receptor for Coxsackie B viruses and adenoviruses 2 and 5 . Science. 1997;275(5304):1320-1323.

29. Wu E, Trauger SA, Pache L, et al. Membrane cofactor protein is a receptor for adenoviruses associated with epidemic keratoconjunctivitis. J Virol. 2004;78(8):3897-3905.

30. Arnberg N, Edlund K, Kidd AH, Wadell G. Adenovirus type 37 uses sialic acid as a cellular receptor. J Virol. 2000;74(1):42-48.

31. Wang H, Li ZY, Liu Y, et al. Desmoglein 2 is a receptor for adenovirus serotypes 3, 7, 11 and 14. Nat Med. 2011;17(1):96-104.

32. Dechecchi MC, Melotti P, Bonizzato A, Santacatterina M, Chilosi M, Cabrini G. Heparan sulfate glycosaminoglycans are receptors sufficient to mediate the initial binding of adenovirus types 2 and 5 . J Virol. 2001;75(18):8772-8780.

33. Short JJ, Pereboev AV, Kawakami Y, Vasu C, Holterman MJ, Curiel DT. Adenovirus serotype 3 utilizes CD80 (B7.1) and CD86 (B7.2) as cellular attachment receptors. Virology. 2004;322(2):349-359.

34. Nilsson EC, Storm RJ, Bauer J, et al. The GD1a glycan is a cellular receptor for adenoviruses causing epidemic keratoconjunctivitis. Nat Med. 2011;17(1):105-109.

35. Wolfrum N, Greber UF. Adenovirus signalling in entry. Cell Microbiol. 2013;15(1):53-62.

36. Xia D, Henry LJ, Gerard RD, Deisenhofer J. Crystal structure of the receptor-binding domain of adenovirus type 5 fiber protein at $1.7 \mathrm{~A}$ resolution. Structure. 1994;2(12):1259-1270.

37. Smith JG, Wiethoff CM, Stewart PL, Nemerow GR. Adenovirus. Curr Top Microbiol Immunol. 2010;343:195-224.

38. Gunther PS, Mikeler E, Hamprecht K, Schneider-Schaulies J, Jahn G, Dennehy KM. CD209/DC-SIGN mediates efficient infection of monocyte-derived dendritic cells by clinical adenovirus $2 \mathrm{C}$ isolates in the presence of bovine lactoferrin. J Gen Virol. 2011;92(Pt 8):1754-1759

39. Li E, Stupack D, Klemke R, Cheresh DA, Nemerow GR. Adenovirus endocytosis via $\alpha_{\mathrm{v}}$ integrins requires phosphoinositide-3-OH kinase. J Virol. 1998;72(3):2055-2061.

40. Mathias P, Wickham T, Moore M, Nemerow G. Multiple adenovirus serotypes use $\alpha_{\mathrm{v}}$ integrins for infection. JVirol. 1994;68(10):6811-6814.

41. Yousuf MA, Zhou X, Mukherjee S, et al. Caveolin-1 associated adenovirus entry into human corneal cells. PLoS One. 2013;8(10):e77462.

42. Rajaiya J, Xiao J, Rajala RV, Chodosh J. Human adenovirus type 19 infection of corneal cells induces p38 MAPK-dependent interleukin-8 expression. Virol J. 2008;5:17.

43. Li E, Stupack D, Bokoch GM, Nemerow GR. Adenovirus endocytosis requires actin cytoskeleton reorganization mediated by Rho family GTPases. J Virol. 1998;72(11):8806-8812.

44. Rodriguez E, Everitt E. Adenovirus uncoating and nuclear establishment are not affected by weak base amines. J Virol. 1996;70(6):3470-3477.

45. Wiethoff CM, Wodrich H, Gerace L, Nemerow GR. Adenovirus protein VI mediates membrane disruption following capsid disassembly. $J$ Virol. 2005;79(4):1992-2000.

46. Greber UF, Webster P, Weber J, Helenius A. The role of the adenovirus protease on virus entry into cells. EMBO J. 1996;15(8):1766-1777.

47. Greber UF, Willetts M, Webster P, Helenius A. Stepwise dismantling of adenovirus 2 during entry into cells. Cell. 1993;75(3):477-486.

48. Saphire AC, Guan T, Schirmer EC, Nemerow GR, Gerace L. Nuclear import of adenovirus DNA in vitro involves the nuclear protein import pathway and hsc70. J Biol Chem. 2000;275(6):4298-4304.

49. Leopold PL, Kreitzer G, Miyazawa N, et al. Dynein- and microtubulemediated translocation of adenovirus serotype 5 occurs after endosomal lysis. Hum Gene Ther. 2000;11(1):151-165. 
50. Chung YS, Kim MK, Lee WJ, Kang C. Silencing E1A mRNA by RNA interference inhibits adenovirus replication. Arch Virol. 2007;152(7): 1305-1314.

51. Pozzuto T, Röger C, Kurreck J, Fechner H. Enhanced suppression of adenovirus replication by triple combination of anti-adenoviral siRNAs, soluble adenovirus receptor trap sCAR-Fc and cidofovir. Antiviral Res. 2015;120:72-78.

52. Liu H, Naismith JH, Hay RT. Adenovirus DNA replication. Curr Top Microbiol Immunol. 2003;272:131-164.

53. Martinez-Aguado P, Serna-Gallego A, Marrugal-Lorenzo JA, Gomez-Marin I, Sanchez-Cespedes J. Antiadenovirus drug discovery: potential targets and evaluation methodologies. Drug Discov Today. 2015;20(10):1235-1242.

54. Bos JL, ten Wolde-Kraamwinkel HC. The E1b promoter of Ad12 in mouse $\mathrm{L}$ tk-cells is activated by adenovirus region E1a. EMBO J. 1983;2(1):73-76.

55. Kneidinger D, Ibrisimovic M, Lion T, Klein R. Inhibition of adenovirus multiplication by short interfering RNAs directly or indirectly targeting the viral DNA replication machinery. Antiviral Res. 2012;94(3):195-207.

56. Lindenbaum JO, Field J, Hurwitz J. The adenovirus DNA binding protein and adenovirus DNA polymerase interact to catalyze elongation of primed DNA templates. J Biol Chem. 1986;261(22):10218-10227.

57. van Breukelen B, Brenkman AB, Holthuizen PE, van der Vliet PC. Adenovirus type 5 DNA binding protein stimulates binding of DNA polymerase to the replication origin. J Virol. 2003;77(2):915-922.

58. Challberg MD, Desiderio SV, Kelly TJ Jr. Adenovirus DNA replication in vitro: characterization of a protein covalently linked to nascent DNA strands. Proc Natl Acad Sci U S A. 1980;77(9):5105-5109.

59. Hoeben RC, Uil TG. Adenovirus DNA replication. Cold Spring Harb Perspect Biol. 2013;5(3):a013003.

60. Duan D, Sharma P, Dudus L, et al. Formation of adeno-associated virus circular genomes is differentially regulated by adenovirus E4 ORF6 and E2a gene expression. J Virol. 1999;73(1):161-169.

61. Flomenberg PR, Chen M, Horwitz MS. Characterization of a major histocompatibility complex class I antigen-binding glycoprotein from adenovirus type 35 , a type associated with immunocompromised hosts. J Virol. 1987;61(12):3665-3671.

62. Ginsberg HS, Lundholm-Beauchamp U, Horswood RL, et al. Role of early region 3 (E3) in pathogenesis of adenovirus disease. Proc Natl Acad Sci U S A. 1989;86(10):3823-3827.

63. Halbert DN, Cutt JR, Shenk T. Adenovirus early region 4 encodes functions required for efficient DNA replication, late gene expression, and host cell shutoff. J Virol. 1985;56(1):250-257.

64. Evans JD, Hearing P. Distinct roles of the adenovirus E4 ORF3 protein in viral DNA replication and inhibition of genome concatenation. $J$ Virol. 2003;77(9):5295-5304.

65. Weinberg DH, Ketner G. Adenoviral early region 4 is required for efficient viral DNA replication and for late gene expression. $J$ Virol. 1986;57(3):833-838.

66. Wu K, Guimet D, Hearing P. The adenovirus L4-33K protein regulates both late gene expression patterns and viral DNA packaging. $J$ Virol. 2013;87(12):6739-6747.

67. Guimet D, Hearing P. The adenovirus L4-22K protein has distinct functions in the posttranscriptional regulation of gene expression and encapsidation of the viral genome. J Virol. 2013;87(13):7688-7699.

68. Murphy KP, Weaver C. Basic concepts in immunology. In: Janeway's Immunobiology. 9th ed. New York: Garland Science; 2017:1-36.

69. Nguyen EK, Nemerow GR, Smith JG. Direct evidence from singlecell analysis that human $\alpha$-defensins block adenovirus uncoating to neutralize infection. JVirol. 2010;84(8):4041-4049.

70. Smith JG, Nemerow GR. Mechanism of adenovirus neutralization by human alpha-defensins. Cell Host Microbe. 2008;3(1):11-19.

71. Calcedo R, Vandenberghe LH, Roy S, Somanathan S, Wang L, Wilson JM. Host immune responses to chronic adenovirus infections in human and nonhuman primates. J Virol. 2009;83(6):2623-2631.
72. Flint SJ, Enquist LW, Racaniello VR, Skalka AM. Immune defenses. In: Principles of Virology. Vol 2. 3rd ed. Washington, DC: ASM Press; 2009:86-132.

73. Murphy KP, Travers P, Walport M. Basic concepts in immunology. In: Janeway's Immunobiology. 7th ed. New York: Garland Science; 2008:1-38

74. Chintakuntlawar AV, Zhou X, Rajaiya J, Chodosh J. Viral capsid is a pathogen-associated molecular pattern in adenovirus keratitis. PLoS Pathog. 2010;6(4):e1000841.

75. Yawata N, Selva KJ, Liu YC, et al. Dynamic change in natural killer cell type in the human ocular mucosa in situ as means of immune evasion by adenovirus infection. Mucosal Immunol. 2016;9(1):159-170.

76. Murray P, Rosenthal K, Pfaller M. Adenoviruses. In: Medical Microbiology. Philadelphia: Saunders; 2016:418-424.

77. Sumida SM, Truitt DM, Lemckert AA, et al. Neutralizing antibodies to adenovirus serotype 5 vaccine vectors are directed primarily against the adenovirus hexon protein. $J$ Immunol. 2005;174(11):7179-7185.

78. Murphy KP, Weaver, C. The humoral immune response. In: Janeway's Immunobiology. 9th ed. New York: Garland Science; 2017:399-444.

79. Murphy KP, Weaver C. T-cell-mediated immunity. In: Janeway's Immunobiology. 9th ed. New York: Garland Science; 2017: 345-398.

80. Harvey SA, Romanowski EG, Yates KA, Gordon YJ. Adenovirusdirected ocular innate immunity: the role of conjunctival defensin-like chemokines (IP-10, I-TAC) and phagocytic human defensin- $\alpha$. Invest Ophthalmol Vis Sci. 2005;46(10):3657-3665.

81. Burgert HG, Ruzsics Z, Obermeier S, Hilgendorf A, Windheim M, Elsing A. Subversion of host defense mechanisms by adenoviruses. Curr Top Microbiol Immunol. 2002;269:273-318.

82. Mahr JA, Gooding LR. Immune evasion by adenoviruses. Immunol Rev. 1999;168:121-130.

83. Leonard GT, Sen GC. Effects of adenovirus E1A protein on interferonsignaling. Virology. 1996;224(1):25-33.

84. Wold WS, Doronin K, Toth K, Kuppuswamy M, Lichtenstein DL, Tollefson AE. Immune responses to adenoviruses: viral evasion mechanisms and their implications for the clinic. Curr Opin Immunol. 1999;11(4):380-386.

85. Lesokhin AM, Delgado-Lopez F, Horwitz MS. Inhibition of chemokine expression by adenovirus early region three (E3) genes. J Virol. 2002;76(16):8236-8243.

86. Li Y, Kang J, Friedman J, et al. Identification of a cell protein (FIP-3) as a modulator of NF- $\mathrm{KB}$ activity and as a target of an adenovirus inhibitor of tumor necrosis factor alpha-induced apoptosis. Proc Natl Acad Sci U S A. 1999;96(3):1042-1047.

87. Gooding LR, Sofola IO, Tollefson AE, Duerksen-Hughes P, Wold WS The adenovirus $\mathrm{E} 3-14.7 \mathrm{~K}$ protein is a general inhibitor of tumor necrosis factor-mediated cytolysis. J Immunol. 1990;145(9):3080-3086.

88. Lei M, Liu Y, Samuel CE. Adenovirus VAI RNA antagonizes the RNA-editing activity of the ADAR adenosine deaminase. Virology. 1998;245(2):188-196.

89. Vivier E, Tomasello E, Baratin M, Walzer T, Ugolini S. Functions of natural killer cells. Nat Immunol. 2008;9(5):503-510.

90. McSharry BP, Burgert HG, Owen DP, et al. Adenovirus E3/19K promotes evasion of NK cell recognition by intracellular sequestration of the NKG2D ligands major histocompatibility complex class I chain-related proteins A and B. J Virol. 2008;82(9):4585-4594.

91. Roelvink PW, Lizonova A, Lee JG, et al. The coxsackievirus-adenovirus receptor protein can function as a cellular attachment protein for adenovirus serotypes from subgroups A, C, D, E, and F. J Virol. 1998;72(10):7909-7915.

92. Pache L, Venkataraman S, Reddy VS, Nemerow GR. Structural variations in species B adenovirus fibers impact CD46 association. J Virol. 2008;82(16):7923-7931.

93. Wang H, Liaw YC, Stone D, et al. Identification of CD46 binding sites within the adenovirus serotype 35 fiber knob. $J$ Virol. 2007;81(23): 12785-12792. 
94. Persson BD, Reiter DM, Marttila M, et al. Adenovirus type 11 binding alters the conformation of its receptor CD46. Nat Struct Mol Biol. 2007;14(2):164-166.

95. Wold WS, Toth K. Adenovirus vectors for gene therapy, vaccination and cancer gene therapy. Curr Gene Ther. 2013;13(6):421-433.

96. D'Angelo LJ, Hierholzer JC, Keenlyside RA, Anderson LJ, Martone WJ. Pharyngoconjunctival fever caused by adenovirus type 4: report of a swimming pool-related outbreak with recovery of virus from pool water. J Infect Dis. 1979;140(1):42-47.

97. Kaneko H, Suzutani T, Aoki K, et al. Epidemiological and virological features of epidemic keratoconjunctivitis due to new human adenovirus type 54 in Japan. Br J Ophthalmol. 2011;95(1):32-36.

98. Giladi N, Herman J. Pharyngoconjunctival fever. Arch Dis Child. 1984;59(12):1182-1183.

99. Gordon YJ, Aoki K, Kinchington PR. Adenovirus keratoconjunctivitis. In: Pepose JS, Holland GN, Wilhelmus KR, editors. Ocular Infection and Immunity. St Louis: Mosby; 1996:877-894.

100. Darougar S, Grey RH, Thaker U, McSwiggan DA. Clinical and epidemiological features of adenovirus keratoconjunctivitis in London. Br J Ophthalmol. 1983;67(1):1-7.

101. Laibson PR. Ocular adenoviral infections. Int Ophthalmo Clin. 1984;24(2):49-64.

102. Bialasiewicz A, Brehler R, Draeger J, Schmitz H. Mathematical modelling of epidemics under specific regard of adenoviral keratoconjunctivitis. Eur J Med Res. 2008;13(8):355-365.

103. Butt AL, Chodosh J. Adenoviral keratoconjunctivitis in a tertiary care eye clinic. Cornea. 2006;25(2):199-202.

104. Massey J, Henry R, Minnich L, Lamson DM, St George K. Notes from the field: health care-associated outbreak of epidemic keratoconjunctivitis - West Virginia, 2015. MMWR Morb Mortal Wkly Rep. 2016;65(14):382-383.

105. Sundaramoorthy R, Dhodapkar R, Kaliaperumal S, Harish BN. Outbreak of adenovirus serotype 8 keratoconjunctivitis in Puducherry, South India: a molecular epidemiological study. J Infect Dev Ctries. 2016;10(4):449-452.

106. Horton JC, Miller S. Magnetic resonance imaging in epidemic adenoviral keratoconjunctivitis. JAMA Ophthalmol. 2015;133(8):960-961.

107. Mukherjee S, Zhou X, Rajaiya J, Chodosh J. Ultrastructure of adenovirus keratitis. Invest Ophthalmol Vis Sci. 2015;56(1):472-477.

108. Rajaiya J, Sadeghi N, Chodosh J. Specific NFkB subunit activation and kinetics of cytokine induction in adenoviral keratitis. Mol Vis. 2009; 15:2879-2889.

109. Lingel NJ, Casser L. Diseases of the cornea. In: Bartlett JD, Jaanus SD, editors. Clinical Ocular Pharmacology. 4th ed. Boston: Butterworth Heinemann; 2001:673-700.

110. Kurna SA, Altun A, Oflaz A, Arsan AK. Evaluation of the impact of persistent subepithelial corneal infiltrations on the visual performance and corneal optical quality after epidemic keratoconjunctivitis. Acta Ophthalmol. 2015;93(4):377-382.

111. Chodosh J, Astley RA, Butler MG, Kennedy RC. Adenovirus keratitis: a role for interleukin-8. Invest Ophthalmol Vis Sci. 2000;41(3):783-789.

112. Chodosh J. Human adenovirus type 37 and the BALB/c mouse: progress toward a restricted adenovirus keratitis model (an American Ophthalmological Society thesis). Trans Am Ophthalmol Soc. 2006;104:346-365.

113. Xiao J, Chodosh J. JNK regulates MCP-1 expression in adenovirus type 19-infected human corneal fibroblasts. Invest Ophthalmol Vis Sci. 2005;46(10):3777-3782.

114. Kaye SB, Lloyd M, Williams H, et al. Evidence for persistence of adenovirus in the tear film a decade following conjunctivitis. $J$ Med Virol. 2005;77(2):227-231.

115. Gibson JA, Darougar S, McSwiggan DA, Thaker U. Comparative sensitivity of a cultural test and the complement fixation test in the diagnosis of adenovirus ocular infection. Br J Ophthalmol. 1979;63(9):617-620.

116. Jin XH, Ishii A, Aoki K, Ishida S, Mukasa K, Ohno S. Detection of human adenovirus hexon antigen using carbon nanotube sensors. $J$ Virol Methods. 2011;171(2):405-407.
117. Caliendo AM, Gilbert DN, Ginocchio CC, et al. Better tests, better care: improved diagnostics for infectious diseases. Clin Infect Dis. 2013;57(Suppl 3):S139-S170.

118. Sambursky R, Tauber S, Schirra F, Kozich K, Davidson R, Cohen EJ. The RPS adeno detector for diagnosing adenoviral conjunctivitis. Ophthalmology. 2006;113(10):1758-1764.

119. Kaufman HE. Adenovirus advances: new diagnostic and therapeutic options. Curr Opin Ophthalmol. 2011;22(4):290-293.

120. Sambursky R, Trattler W, Tauber S, et al. Sensitivity and specificity of the AdenoPlus test for diagnosing adenoviral conjunctivitis. JAMA Ophthalmol. 2013;131(1):17-22.

121. Muller MP, Siddiqui N, Ivancic R, Wong D. Adenovirus-related epidemic keratoconjunctivitis outbreak at a hospital-affiliated ophthalmology clinic. Am J Infect Control. 2018;46(5):581-583.

122. Alai N. Enhancing best practices in ophthalmology for prevention of nosocomial epidemic keratoconjunctivitis infections. Curr Med Res Opin. 2016;32(10):1757-1758.

123. Meyer-Rusenberg B, Loderstadt U, Richard G, Kaulfers PM, Gesser C. Epidemic keratoconjunctivitis: the current situation and recommendations for prevention and treatment. Dtsch Arztebl Int. 2011;108(27):475-480.

124. Centers for Disease Control and Prevention. Guide to infection prevention for outpatient settings: minimum expectations for safe care. 2016. Available from: https://www.cdc.gov/hai/settings/outpatient/ outpatient-care-guidelines.html. Accessed April 28, 2018.

125. Jernigan JA, Lowry BS, Hayden FG, et al. Adenovirus type 8 epidemic keratoconjunctivitis in an eye clinic: risk factors and control. $J$ Infect Dis. 1993;167(6):1307-1313.

126. Kinchington PR, Romanowski EG, Jerold Gordon Y. Prospects for adenovirus antivirals. J Antimicrob Chemother. 2005;55(4):424-429.

127. Clement C, Capriotti JA, Kumar M, et al. Clinical and antiviral efficacy of an ophthalmic formulation of dexamethasone povidone-iodine in a rabbit model of adenoviral keratoconjunctivitis. Inves Ophthalmol Vis Sci. 2011;52(1):339-344.

128. Hillenkamp J, Reinhard T, Ross RS, et al. The effects of cidofovir $1 \%$ with and without cyclosporin A $1 \%$ as a topical treatment of acute adenoviral keratoconjunctivitis: a controlled clinical pilot study. Ophthalmology. 2002;109(5):845-850.

129. Huang J, Kadonosono K, Uchio E. Antiadenoviral effects of ganciclovir in types inducing keratoconjunctivitis by quantitative polymerase chain reaction methods. Clin Ophthalmol. 2014;8:315-320.

130. Naesens L, Lenaerts L, Andrei G, et al. Antiadenovirus activities of several classes of nucleoside and nucleotide analogues. Antimicrob Agents Chemother. 2005;49(3):1010-1016.

131. Toth K, Ying B, Tollefson AE, et al. Valganciclovir inhibits human adenovirus replication and pathology in permissive immunosuppressed female and male Syrian hamsters. Viruses. 2015;7(3):1409-1428.

132. Ying B, Tollefson AE, Spencer JF, et al. Ganciclovir inhibits human adenovirus replication and pathogenicity in permissive immunosuppressed Syrian hamsters. Antimicrob Agents Chemother. 2014;58(12):7171-7181.

133. Tabbara KF, Jarade EF. Ganciclovir effects in adenoviral keratoconjunctivitis. Invest Ophthalmol Vis Sci. 2001;42(4):S579.

134. Nwanegbo EC, Romanowski EG, Gordon YJ, Gambotto A. Efficacy of topical immunoglobulins against experimental adenoviral ocular infection. Invest Ophthalmol Vis Sci. 2007;48(9):4171-4176.

135. Paolino K, Sande J, Perez E, et al. Eradication of disseminated adenovirus infection in a pediatric hematopoietic stem cell transplantation recipient using the novel antiviral agent CMX001. J Clin Virol. 2011;50(2):167-170.

136. Grimley MS, Chemaly RF, Englund JA, et al. Brincidofovir for asymptomatic adenovirus viremia in pediatric and adult allogeneic hematopoietic cell transplant recipients: a randomized placebo-controlled phase II trial. Biol Blood Marrow Transplant. 2017;23(3):512-521.

137. Toth K, Tollefson AE, Spencer JF, Ying B, Wold WS. Combination therapy with brincidofovir and valganciclovir against species $C$ adenovirus infection in the immunosuppressed Syrian hamster model allows for substantial reduction of dose for both compounds. Antiviral Res. 2017;146:121-129. 
138. Feuchtinger T, Matthes-Martin S, Richard C, et al. Safe adoptive transfer of virus-specific T-cell immunity for the treatment of systemic adenovirus infection after allogeneic stem cell transplantation. $\mathrm{Br} J$ Haematol. 2006;134(1):64-76.

139. Zandvliet ML, Falkenburg JH, van Liempt E, et al. Combined CD8+ and CD4+ adenovirus hexon-specific $\mathrm{T}$ cells associated with viral clearance after stem cell transplantation as treatment for adenovirus infection. Haematologica. 2010;95(11):1943-1951.

140. Feuchtinger T, Richard C, Joachim S, et al. Clinical grade generation of hexon-specific $\mathrm{T}$ cells for adoptive T-cell transfer as a treatment of adenovirus infection after allogeneic stem cell transplantation. $J$ Immunother. 2008;31(2):199-206.

141. Pelletier JS, Stewart K, Trattler W, et al. A combination povidone-iodine $0.4 \%$ dexamethasone $0.1 \%$ ophthalmic suspension in the treatment of adenoviral conjunctivitis. Adv Ther. 2009;26(8):776-783.
142. Kovalyuk N, Kaiserman I, Mimouni M, et al. Treatment of adenoviral keratoconjunctivitis with a combination of povidone-iodine $1.0 \%$ and dexamethasone $0.1 \%$ drops: a clinical prospective controlled randomized study. Acta Ophthalmol. 2017;95(8):e686-e692.

143. Levinger E, Trivizki O, Shachar Y, Levinger S, Verssano D. Topical $0.03 \%$ tacrolimus for subepithelial infiltrates secondary to adenoviral keratoconjunctivitis. Graefes Arch Clin Exp Ophthalmol. 2014;252(5):811-816.

144. Ibrisimovic M, Kneidinger D, Lion T, Klein R. An adenoviral vectorbased expression and delivery system for the inhibition of wild-type adenovirus replication by artificial microRNAs. Antiviral Res. 2013;97(1): $10-23$.

145. Nikitenko NA, Speiseder T, Lam E, et al. Regulation of human adenovirus replication by RNA interference. Acta Naturae. 2015;7(3) $100-107$.
Infection and Drug Resistance

\section{Publish your work in this journal}

Infection and Drug Resistance is an international, peer-reviewed openaccess journal that focuses on the optimal treatment of infection (bacterial, fungal and viral) and the development and institution of preventive strategies to minimize the development and spread of resistance. The journal is specifically concerned with the epidemiology of antibiotic

\section{Dovepress}

resistance and the mechanisms of resistance development and diffusion in both hospitals and the community. The manuscript management system is completely online and includes a very quick and fair peerreview system, which is all easy to use. Visit http://www.dovepress.com/ testimonials.php to read real quotes from published authors. 